\title{
繊維補強コンクリートの曲げ破壊挙動に関する解析的研究 ANALYTICAL STUDY ON BENDING FRACTURE BEHAVIOR OF FIBER REINFORCED CONCRETE
}

\author{
平岩 陸*, 谷川恭雄**, 朴 相 俊*** \\ Takashi HIRAIWA, Yasuo TANIGAWA and SangJun PARK
}

\begin{abstract}
In fiber reinforced concrete, fibers are added to improve the brittle fracture of plain concrete. However, the relationship between the fracture behavior of fiber reinforced concrete and the property of fiber is not necessarily grasped. In this paper, in order to investigate the bending fracture behavior of fiber reinforced concrete, an analytical study is carried out by visco-elastoplastic suspension element method (VEPSEM). The fiber element simulated as static elastoplastic element in earlier VEPSEM is modelled as dynamic element in this analysis. It is shown that the analytical results obtained by using this dynamic fiber element can comparatively express the experimental ones. The maximum load becomes high and the descending portion of loaddeflection curve becomes ductile. The cause of these results can be explained from the internal cracks occurred by bridging effect of fiber.
\end{abstract}

\footnotetext{
Keywords : fiber reinforced concrete, dynamic fiber element, bending test, non-continuum model, dynamic analysis, visco-elasto-plastic suspension element method 繊維補強コンクリート、動的繊維要素、曲げ試験、非連続体モデル、動的解析、 粘弾塑性サスペンション要素法
}

\section{1.まえがき}

繊維補強コンクリートは、コンクリート特有の脆性的な破壊性状 を改善し、勒性的な破壊性状を付与することを目的として、コンク リートに各種の繊維を混入した複合材料である。代表的な緎維とし て鋼緎維”が挙げられ、広く用いられているが、他にもガラス緎

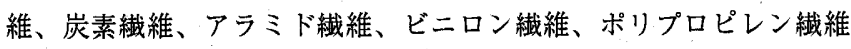
などがあり、現在も様々な緎維の開発および適用が行われている。 しかし、新しく開発された緎維を混入したコンクリートが、どのよ うな性質を持つかについては、引張試験や曲げ試験などの実験を行 って検証するしかないのが現状である。これは、織維の性質と、そ れを混入した繊維補強コンクリートの性質の関連が明確になってい ないためである。このため、この関連を理論的に考察する試みが並 行して行われている2-5)。

一般には、緎維混入による脆性的な破壊性状の改善は、コンク リートに発生したひび割れの拡大を繊維が防止する架橋効果による ものと説明されており、様々なモデルが提案されている。しかし、 この架橋効果は、織維抢よびマトリックスの力学性質だけではな く、繊維とマトリックスの付着性状によって影響を受ける。さらに 繊維の分散状況およびひび割れとの位置関係によっても変化するた め、纎維混入の効果を繊維補強コンクリート全体の力学性状として
評価することは困難である。これらの理由により、瀻維補強コンク リートの力学的性質を瀻維の性質から評価できるモデルは現状では 存在しない。

筆者らは既に、コンクリートの破壊解析手法として、非連続体モ デルを用いる点および動的な解析を行う点に特徵のある粘弾塑性サ スペンション要素法 (VEPSEM) を提案し、コンクリートの破壊シミ ユレーション行い、本解析手法の適用性を検討してきた6.7。既報》で は、VEPSEMにおける解析モデルに、特定の2節点間の変形の増大 を静的に拘束する単純な瀻維要素を導入することによって、瀻維補 強コンクリートの直接引張試験のシミュレーションを行った。しか し、この方法では、曲げ解析など大変形が生じる場合に安定した結 果が得られないという問題点があった。この問題を改善するには、 纎維補強コンクリートの繊維要素を、より実現象に近いモデルとし て、動的な弾塑性要素とする必要があった。本論文は、㵶維を模擬 するために動的な弾塑性要素を導入した解析手法により、瀻維補強 コンクリートの曲げ破壊解析を行った結果を示すものである。

\section{2. 解析方法}

解析方法の詳細については、既報67を参照されたい。 ここでは、本解析に導入した動的な弾塑性要素について説明す
$*$ 豊田工業高等専門学校建築学科 助手・博士 (工学)

***名城大学理工学部建築学科 教授. 工博

**** 東京理科大学総合研究所火災科学研究センター $\mathrm{COE}$ 研究員·博士 (工学)
Research Assoc., Dept. of Architecture, Toyota National College of Tech., Dr. Eng. Prof., Dept. of Architecture, Faculty of Science and Tech., Meijo Univ., Dr. Eng. COE-Researcher, Center for Fire Science and Tech., Tokyo Univ. of Science, Dr. Eng. 

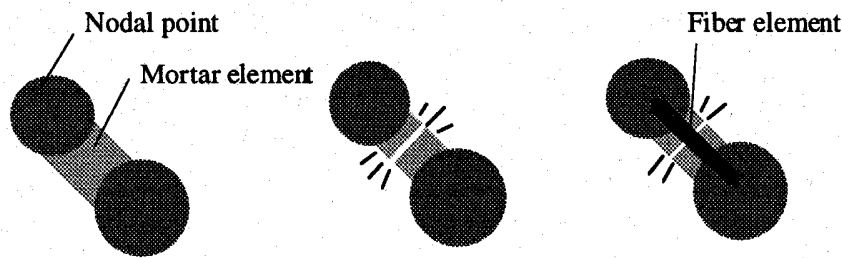

(1) 解析モデルの構成

(2) ひび割れの表現

(3) 架橋効果の表現

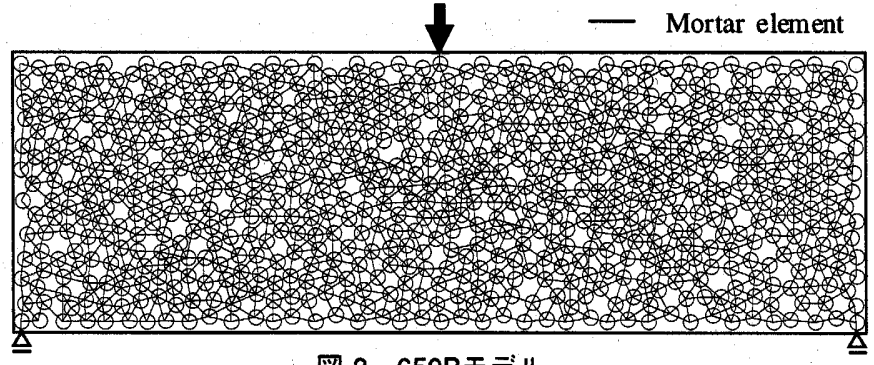

図-3，650Bモデル

表-1 モルタルの入カデータ

\begin{tabular}{c|c|c|c|c|c|c|c}
\hline $\tan \phi$ & $F t$ & $E$ & $\eta$ & $v$ & $d$ & $H$ & $D$ \\
\hline 0.3 & 3.0 & 19.6 & 0.3 & 0.05 & 5.0 & 100 & 300 \\
\hline
\end{tabular}

[Notes] $\tan \phi:$ Coefficient of internal friction, $F t$ : Pure tensile strength (MPa), $E$ : Elastic modulus (GPa), $\eta$ : Viscosity (MPa $\cdot \mathrm{s}), v$ : Shear loading rate $(\mathrm{cm} / \mathrm{s}), d$ :Diameter of nodal point $(\mathrm{mm}), \dot{H}$ : Height of specimen $(\mathrm{mm}), D:$ Width of specimen $(\mathrm{mm})$

る。図-1は、本解析における織維の構成モデルの概念図を示したも のである。この図に示すように、解析モデルは節点とモルタル要素 から構成されており、構成則に従いモル夕ル要素が消失することで コンクリートのひび割れを表現している。本研究では、このような 節点間を動的な弾塑性要素により結ぶことで䋳維補強を考慮した。 この弾塑性要素は、図-2に示すバイリニア型の応力ーひずみ関係の

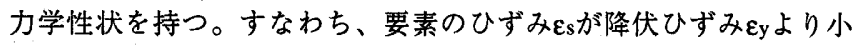
さい範囲では、要素は弾性であり、Esが无を超えれば、要素は降伏 し、それ以降は、ひずみが増大しても抵抗応力は降伏応力 $\sigma_{\mathrm{y}}$ の一定 值となる。この要素による抵抗力が、ひび割れの発生後、つまりモ ルタル要素が消失した後にも生じ続けることによって、本要素は織 維による架橋効果を模擬している。既報りと異なる点は、この纎維 要素が運動方程式に組み込まれ、動的な変形挙動を表現できる点で

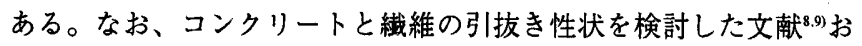

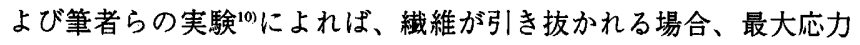
後に応力が低下することや、引抜けに対して配向角の影響が存在す ることが指摘されているが、今回の解析では単純化のため最も単純 なバイリニア型の応力ーひずみ関係を用いた。このため、本解析で は、繊維のコンクリートからの抜出しおよびひび割れに対する繊維 の配向角の影響は考慮していないことになる。

織維要素は、基本として弾性係数Es $210 \mathrm{GPa}$ 、降伏応力 $\sigma_{y} 300 \mathrm{MPa}$ の一般の鋼材を想定している。実際の解析においては、これに断面 皘を乗ずることによって計算を行っている。本解析において、瀻維 補強の効果がある程度現れる範囲で、断面積を設定したところ $2 \mathrm{~mm}^{2}$

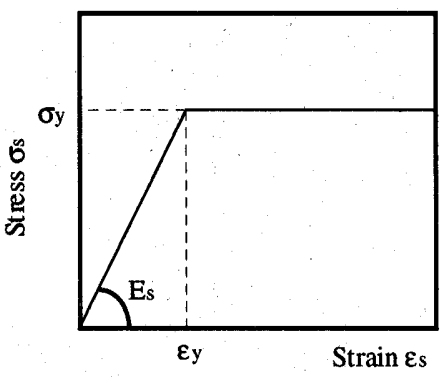

図-2 織維要素の構成則

程度となり、一般の瀻維よりも太いものとなったが、本解析は2次 元解析であるため、このような実現象との差が生じたものと考えら れる。また、本解析においては、繊維断面積に繊維長さを乗じ、そ れを全て足したものを緎維体積と考え、この瀻維体積と、解析モデ ルの全体積との比率を織維混入率と定義している。この定義に従っ て計算すると、瀻維の断面積が $2 \mathrm{~mm}^{2}$ の時の緎維混入率は約 $1 \%$ とな った。

解析モデルは、図-3に示すように、650個の節点をランダムに配 置した650Bモデルであり、中央一点集中載荷による曲げ試験のシミ ユレーションを行った。また、モルタル要素の入力データは表-1に 示す通りである。

以上のように、動的な繊維要素を加えた解析手法を用いて、繊維 混入率 $p$ 、繊維長さ $L f$ 、瀻維の配向性、さらに繊維の性質として弾 性係数Es および降伏応力 $\sigma_{y}$ が、緎維補強コンクリートの曲げ破壊 挙動に及ほす影響について検討した。

\section{3. 解析結果および考察}

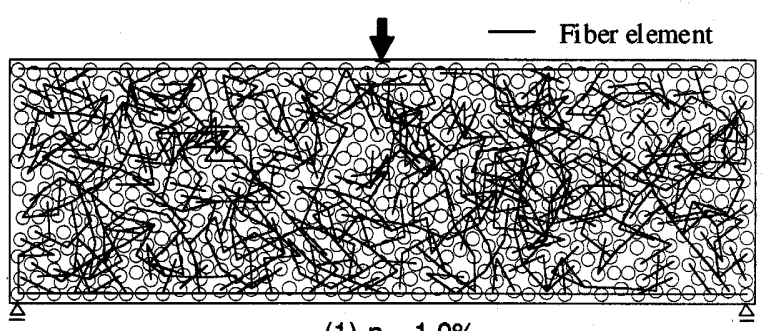

(1) $p=1.0 \%$

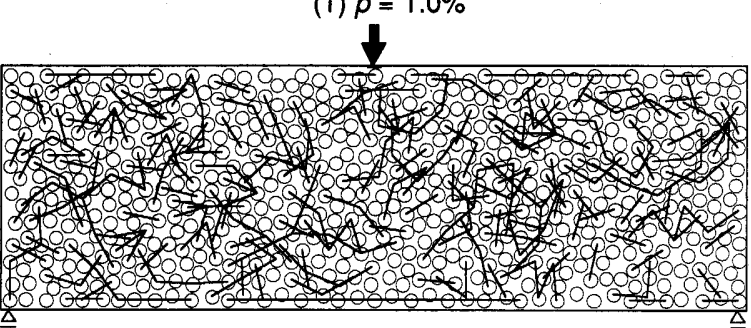

(2) $p=0.5 \%$

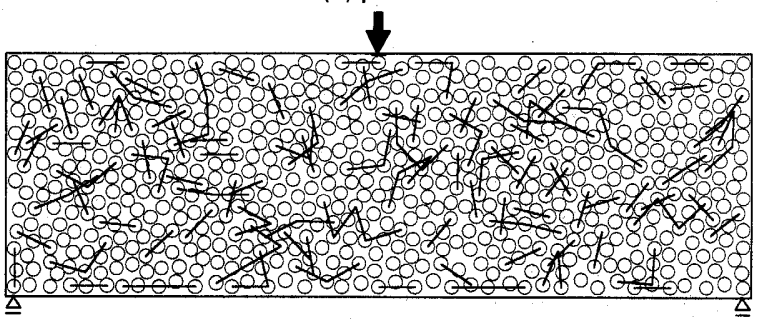

(3) $p=0.25 \%$

図-4 解析モデル（繊維混入率pの变化：Lf=1cm） 


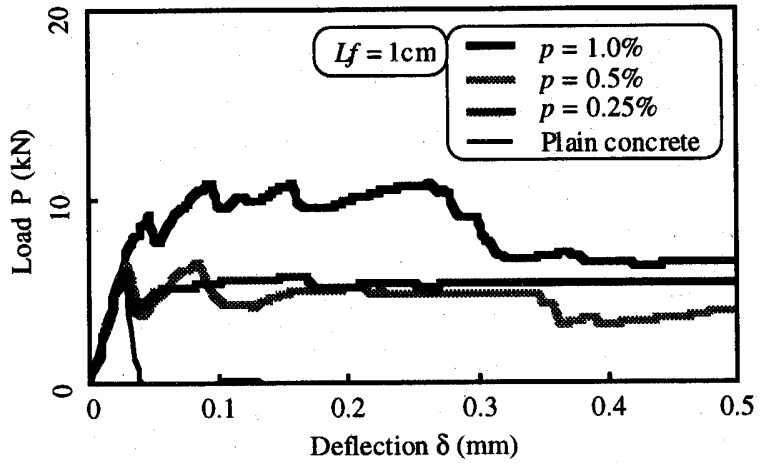

图-5 荷重P一中央点たわみ $\delta$ 曲線（㵶維混入率 $p$ の影留）

\section{1 緎維混入率 $p$ の影零}

図-4は、織維混入率 $p$ を模擬して、織維要素の本数を変化させた 場合の解析モデルを示したものである。緎維長さ $L f=1 \mathrm{~cm}$ で、織維 混入率 $p=1.0 \%$ とし、配置をランダムとしたものを基本とし、本数 を1/2,1/4 と隇らしている。よって、織維混入率はそれぞれ1.0, 0.5, $0.25 \%$ となる。図-5は、これらのモデルを用いた場合の荷重P一中央 点たわみ反曲線を示したものである。この図によると、プレーンコ ンクリートは最大荷重に達したのち、荷重が一気に低下しているこ とがわかる。これに対して、織維を混入したものは最大荷重が増加 するとともに、最大荷重後も耐力を保持しており、さらにその傾向 は織維混入率が大きいものほど大きい。これらの結果は、図-6に示 す各轼維混入率の最終的な破壊状況から説明できる。すなわち、プ レーンコンクリートにお゙いては、供試体下部の中央部付近にひび割 れが生じ、それが一直線に供試体を貫き、供試体上部まで到達して おり、供試体が折れるような形で破壊している。これが最大荷重後 に一気に荷重が低下する原因と考えられる。一方、緎維を混入した ものでは、プレーンコンクリートで生じたひび割れの周りにもひび 割れが生じている。これは、緎維の架橋効果により、ひび割れ幅の 拡大が抑制され、その周りにひび割れが生じるものと考えられる。 また、繊維混入率が大きくなるにつれて、より広い範囲にひび割れ が生じており、馀維による架橋効果が顕著になることがわかる。こ のような傾向は、実験において観察される結果と同様である。な お、実験においては、最大荷重後に荷重が徐々に低下していくもの も多いが、本解析結果では、荷重が一定值に収束している。これ は、繊維要素の構成則において、繊維の抜けによる降伏後の応力低 下を考虑していないためと考えられる。

\section{2 緎維長さ $L f$ の影霎}

図-7は、瀻維混入率 $p=1.0 \%$ とし、繊維長さ $L f$ を変化させた場合 の解析モデルを示したものである。䄉維の配置については、 $L f=1 \mathrm{~cm}$ のもと同様にランダムであり、これらのモデルを用いて 䄉維長さの影響を考察した。図-8は、これらのモデルを用いた場合 の荷重P一中央点たわみ $\delta$ 曲線を示したものである。この図による と、轼維が長くなると、わずかに最大荷重が低下し、全体の変形挙 動が変化するようであるが、本解析では、織維長さの影響はそれほ ど生じなかったといえる。緎維の形状などにもよるが、緎維が長い

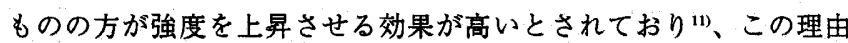
として緎維が長いとひび割れ発生後の引抜き抵抗が增すことが挙げ

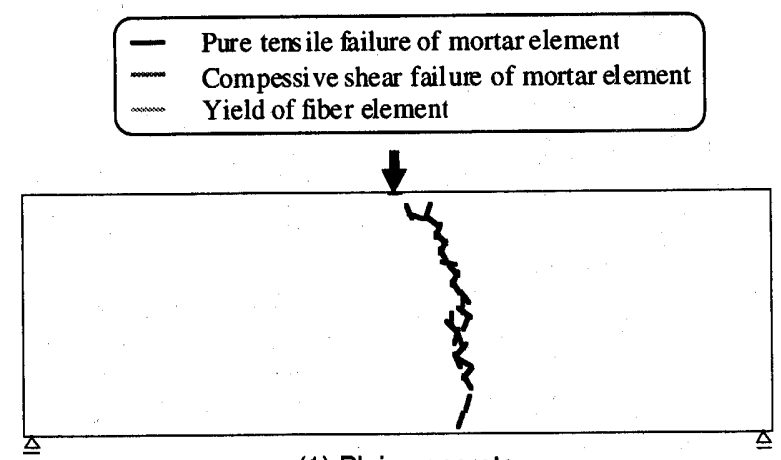

(1) Plain concrete

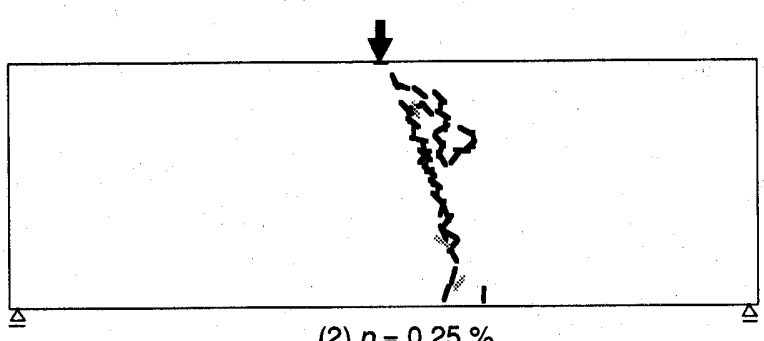

(2) $p=0.25 \%$

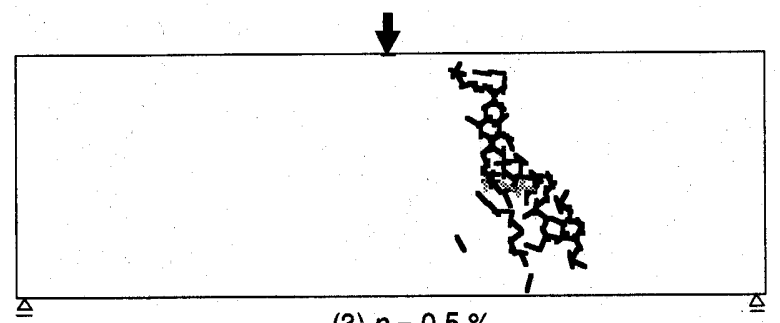

(3) $p=0.5 \%$

$+$

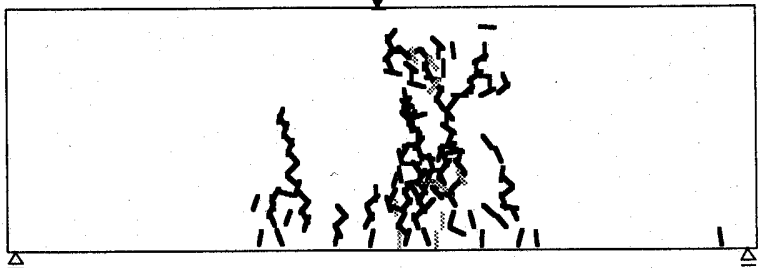

(4) $p=1.0 \%$

図-6＼cjkstart破壞状況（繊維混入率pの影響）

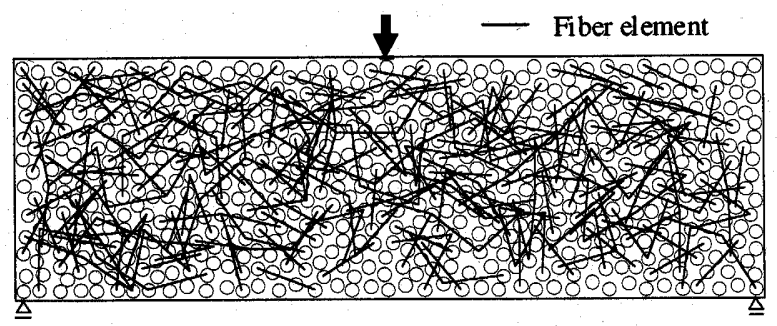

(1) $L f=2 \mathrm{~cm}$

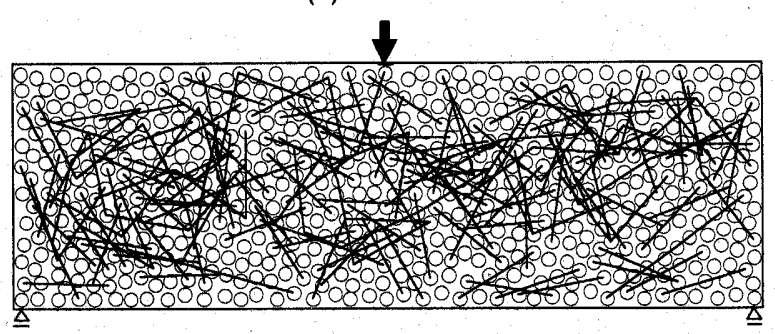

(2) $L f=3 \mathrm{~cm}$

図-7 解析モデル（繊維長さLfの変化： $p=1.0 \%$ ） 


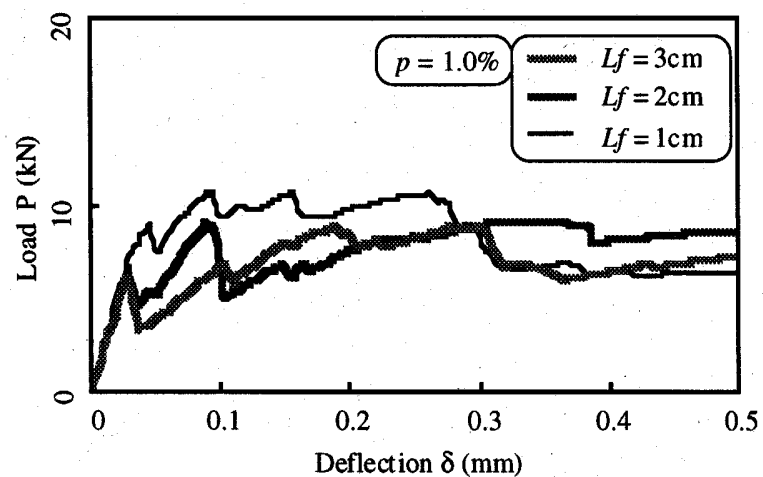

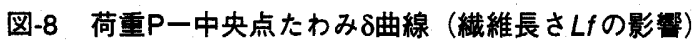

られている。本解析では、繊維の構成則として、降伏後の応力低下 を考虑していないため、このような結果になったものと考えられ る。

\section{3 織維の配向状態の影響}

図-9は、繊維の配向状態を変化させた場合の解析モデルを示した ものである。繊維混入率 $p=1.0 \%$ 、瀻維長さ $L f=1 \mathrm{~cm}$ の解析モデルか ら、縦方向の要素（垂直方向との角度が $45^{\circ}$ 以内の要素）のみのモ デルと、横方向の要素（水平方向との角度が $45^{\circ}$ 以内の要素）のみ のモデルを作成している。縦要素のみのモデルは、もとの緎維要素 のうち46\%の要素を、横要素のみのモデルは、残りの54\%の要素を 使用しているモデルとなった。図-10は、これらのモデルを用いた 場合の荷重P一中央点たわみ反曲線を示したものである。この図によ れば、繊維要素数が約半分しかない横要素のみのモデルにおいて も、全要素のモデルとほほ同様の変形挙動を示していることがわか る。逆に縦要素のみのモデルでは、最大荷重も小さく、その後も一 定值に収束するものの、荷重が小さくなっている。図-11は、これ らの破壊状況を示したものである。この図からも明らかなように、 横要素のみの場合、図-6(4)に示される全要素の結果とほとんど同様 の破壞状況を示しており、曲げ試験においては、横方向の要素の役 割が非常に大きいことがわかる。一方、縦要素のみの場合、図-6(1) に示されるプレーンコンクリートの結果よりも破壊領域が広いもの の、ごくわずかの範囲に破壤が集中しており、瀻維要素の効果があ まり生じないことがわかる。

\section{4 緎維性質の影䇺}

瀻維補強コンクリートに用いられる緎維には、鋼瀻維以外にもガ ラス纎維や炭素緎維など様々な緎維があり、現在も開発が進められ ている。ここでは、緎維の性質が緎維補強コンクリートの曲げ破壤 挙動に及ほす影響について検討するため、緎維要素の入カデータで ある弾性係数Es および降伏応力 $\sigma y$ を変化させた解析を行った。

\section{(1) 弾性係数 Es の影製}

図-12は、弾性係数Es を変化させた場合の荷重P一中央点たわみ $\delta$ 曲線を示したものである。弾性係数が小さい場合、荷重がまだ小さ いときに一時的に低下するが、その後は徐々に荷重が上昇してい く。一方、弾性係数が大きい場合、荷重の上昇率が高く、最大荷重 そのものも大きいが、その後大きく荷重が低下して一定值に収束す している。

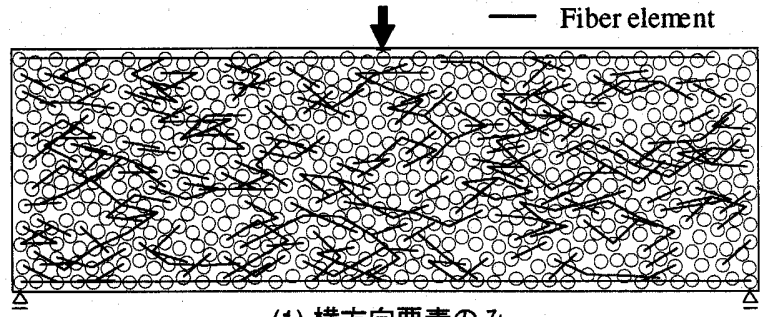

(1) 横方向要素のみ

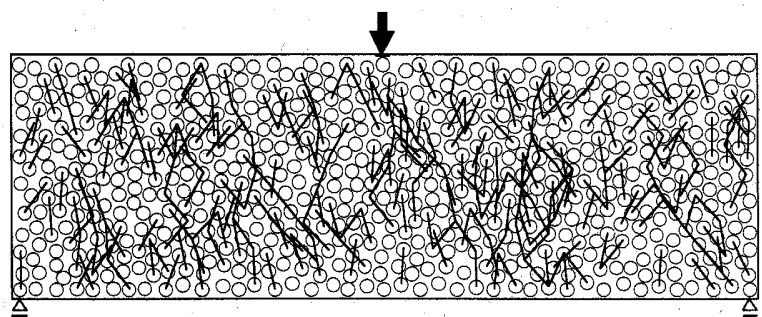

(2) 縦方向要素のみ

図-9 解析モデル（織維の配向状態の変化）

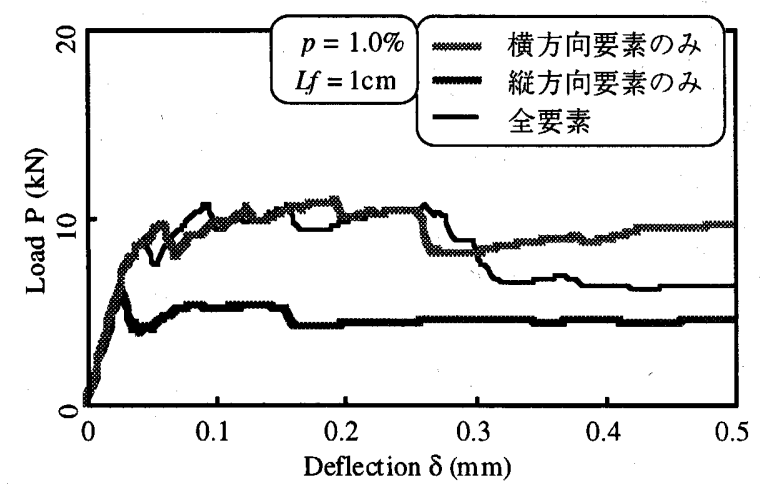

図-10 荷重P一中央点たわみ $\delta$ 曲線（織維の配向状態の影暗）

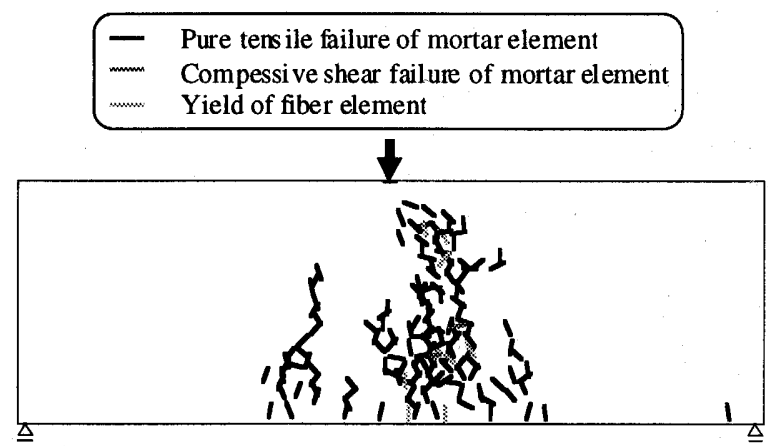

(1) 横方向要素のみ

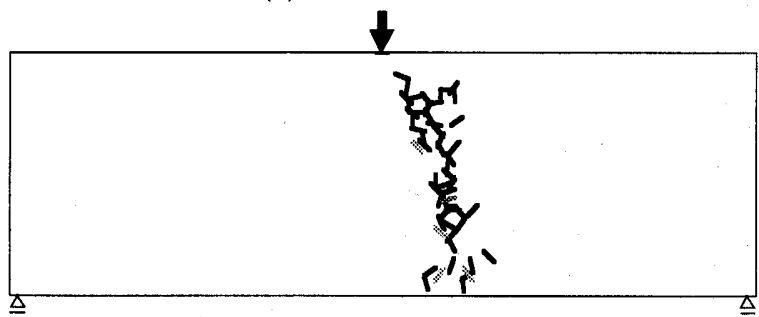

(2) 縦方向要素のみ

図-11＼cjkstart破壊状況（㵶維の配向状態の影響）

図-13は、これらの破壊性状を示したものである。弾性係数が小 さい場合、供試体中央部付近に何本もすじになるようにひび割れが 生じている。これらのすじ状のひび割れは、それぞれ図-12の荷重P 


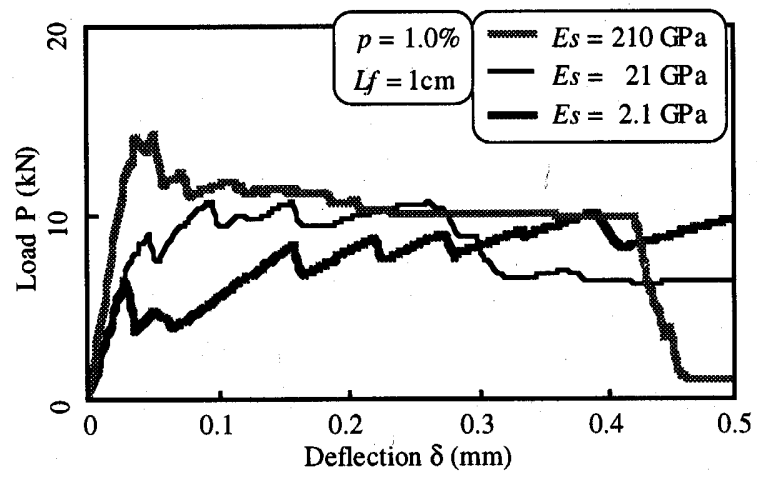

図-12 荷重P一中央点たわみ $\delta$ 曲線（弾性係数Es の影䱥）

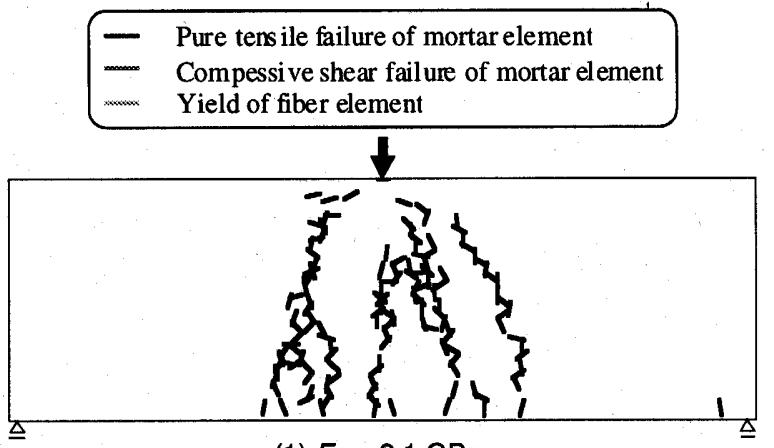

(1) $E s=2.1 \mathrm{GPa}$

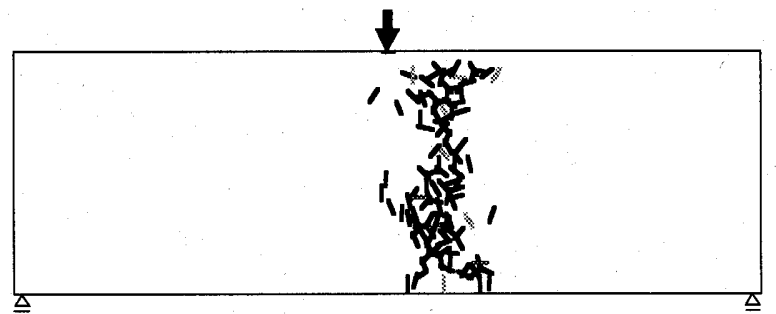

(2) $E s=210 \mathrm{GPa}$

図-13 破懐状況（弾性係数Es の影敏）

一中央点たわみ $\delta$ 曲線において、荷重が一時的に大きく低下したと きに発生している。これは、弾性係数が小さいと、架橋効果が小さ いため、ひび割れ発生後の開口部が広がりやすいものの、広がるに 従って繊維による拘束がさらに増大していくため、それ以上ひび割 れ幅が広がることがなく、次のすじとなるひび割れが生じるものと 考えられる。一方、弾性係数が大きい場合、破壊がすじ状ではな く、狭い範囲に密集して生じている。これは、弾性係数が大きいと わずかなひずみで大きな拘束力が生じるため、ひび割れが発生して その付近の応力のバランスが崩れた場合に、破壤が集中して一気に 生じることを示している。

\section{(2) 降伏応力 $\sigma y$ の影製}

図-14は、降伏応力 $\sigma_{y}$ を変化させた場合の荷重P一中央点たわみ $\delta$ 曲線を示したものである。降伏応力が小さい場合、最大荷重はプ レーンコンクリートよりも大きくなるが、荷重はその後すぐに低下 する。その後、プレーンコンクリートのように応力が0になること はないものの、低い值で収束している。一方、降伏応力が大きくな ると、プレーンコンクリートの最大荷重を超えてさらに荷重が増大 していき、今回の中央点たわみの範囲では、荷重が上昇し続けてい

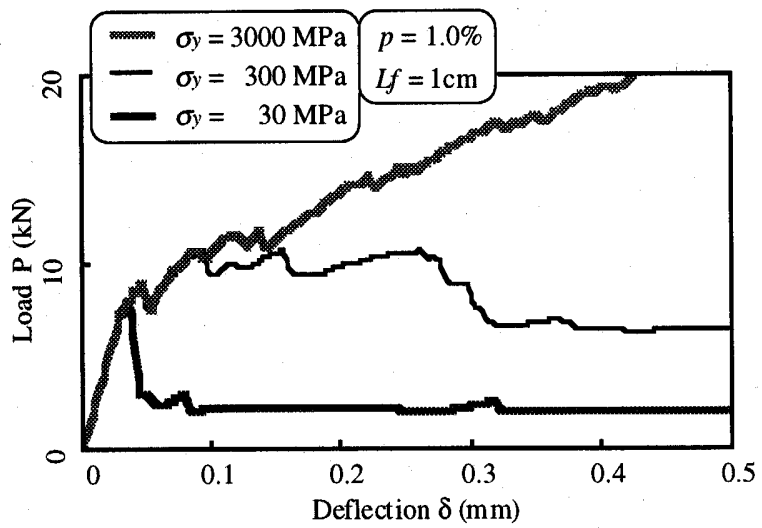

図-14 荷重P一中央点たわみ $\delta$ 曲線（降伏応力 $\sigma_{y}$ の影響）

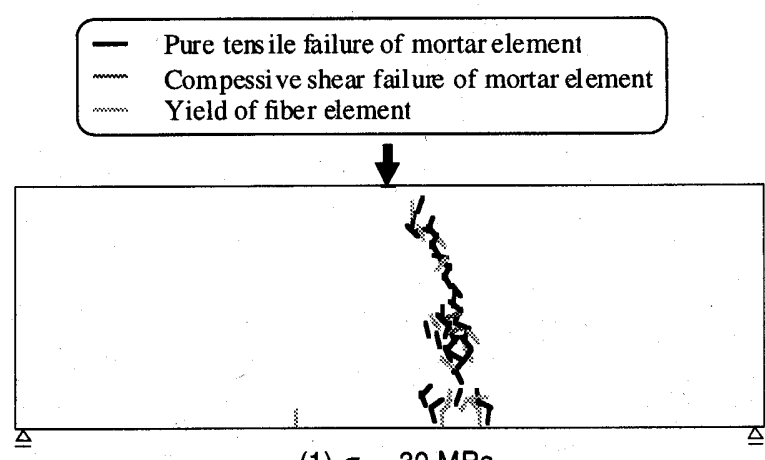

(1) $\sigma_{y}=30 \mathrm{MPa}$

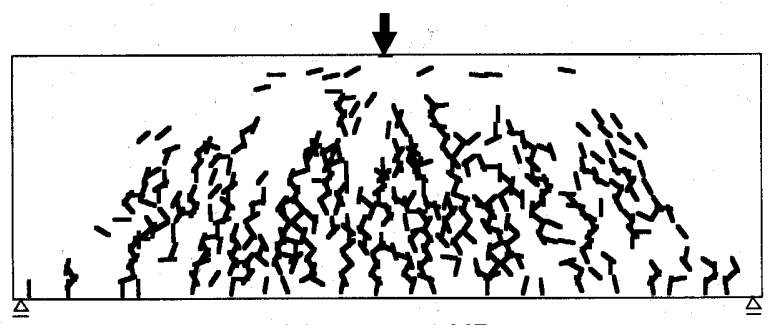

(2) $\sigma_{y}=3000 \mathrm{MPa}$

図-15 破堙状況（降伏応力 $\sigma_{y}$ の影響）

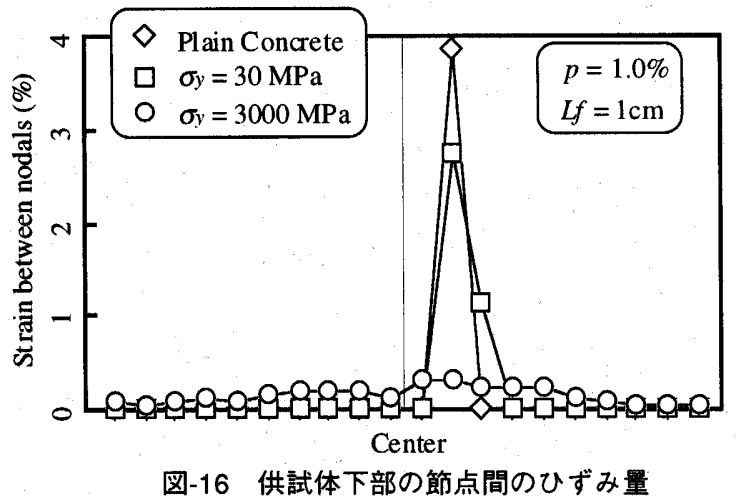

る。

これらの結果が生じる理由は、破壊状況を示した図-15から説明 できる。降伏応力が小さい場合、プレーンコンクリートと同じく、 供試体中央付近のみにひび割れが生じており、全体に広がっていな い。また、その部分の瀻維が降伏している。これは、降伏応力が小 さいため、瀻維がすぐに降伏応力に達し、ひび割れが発生したあと に、その桩大を防止することができないことを示している。ただ 
し、ひび割れが集中しているものの、械維の降伏応力分だけは荷重 を保つことができるため、最終的に荷重が0にはならない。一方、 降伏応力が大きい場合、これとまったく異なり、全体にひび割れが 分散しており、織維の降伏もまったく生じていないことがわかる。 これは、降伏応力が大きくなると、ひび割れ発生後のひび割れ幅の 拡大を確実に防止できるため、供試体全域にひび割れを誘発するこ とになることを示している。これらのことを確認するため、供試体 下部の変形状態を検討した。図-16は、たわみが $0.5 \%$ の時の供試体 下部の節点間のひずみを示したものである。これによると、プレー ンコンクリートでは、供試体中央付近でひずみが突出しており、他 の部分にはほとんどひずみが生じていないことがわかる。一方、緎 維を混入したものでも、降伏值が小さい場合は、中央部付近のひず みは小さくなるものの、それ以外の箇所ではひずみはほとんど生じ ない。しかし、降伏值が大きくなると、供試体下部全域で変形が生 じており、加えて中央部のひずみが非常に小さくなっている。つま り、プレーンコンクリートでは破壊が一点に集中するのに対して、 䄉維補強コンクリートでは、瀻維の架橋効果によって破壊が分散し ており、降伏值が大きい場合にその効果が大きいことが明らかであ る。

\section{4. まとめ}

本研究では、筆者らが開発した粘弾塑性サスペンション要素法 に、動的な緎維要素を導入した場合の、瀻維補強コンクリートの曲 げ破壞挙動の再現性について検討した。その結果、以下のような解 析結果が得られた。

1)緎維を混入することで、プレーンコンクリートに比較して最大荷 重が大きくなり、最大荷重後も耐力を保持した。また、この傾向 は、緎維混入率が大きいほど顕著であった。

2)破壊状態を検討することにより、瀻維の混入による影響が瀻維の 架橋効果によるひび割れの分散に伴うものであることを示した。

3)緎維長さの影響はそれほど生じなかったが、これは樴維の引き抜 き抵抗による架橋効果の減少を考慮していないためと考えられ る。

4)曲げに対して抵抗するのは横方向の緎維要素であり、縦方向の緎 維要素の役割は小さい。

5) 緎維の弾性係数が大きくなると、最大荷重は大きくなるものの、 その後の破壊性状が脆性的になる結果が得られた。
6)䋐維の降伏応力が大きいと、荷重が上昇し続け、ひび割れが供試 体全域に広がっていく結果が得られた。

これらの解析結果は、既往の実験結果の多くを再現している。ま た、弾性係数や降伏値の影響については、予想される破壊挙動を示 しているものと考えられる。よって、本解析手法を用いて繊維補強 コンクリートの曲げ破壊挙動を再現できる可能性があるといえる。 ただし、本解析手法は2次元であり、定性的な再現にとどまってい る。今後は、コンクリートからの繊維の引抜けを考慮した構成則を 導入するとともに、2次元解析と実現象との関連を考察し、定量的 な検討につなげていく予定である。

\section{謝辞}

本研究費の一部は、平成16年度日本学術振興会科学研究費補助金 ・若手研究(B)によった。付記して謝意を表する。

\section{参考文献}

1) 日本建築学会：スチールファイバーコンクリートの現状, 丸善, 1984.3

2) 真嶋光保 ·幸左賢二・大野定俊：瀻維補強セメントルコンクリート複合材 料, 技報堂出版, 1994.5.

3) 松岡茂・堀井秀之：短瀻維補強コンクリートの現状について,コンクリート 工学, Vol.37, No.4, pp.19-24, 1999.4

4) 閑田徹志：高性能瀻維補強セメント材料の設計技術の現状, コンクリート工 学, Vol.38, No.6, pp.9-16, 2000.6

5) 日本コンクリート工学協会：高勒性セメント複合材料の性能評価と構造利 用研究委員会報告書, 2002.1

6) 荒井正直・船見晃啓・黒川善幸・森博嗣・谷川恭雄 : 非連続体モデルを用 いたコンクリートの破壊解析手法, 日本建築学会構造系論文集, No.471, pp.1-9, 1995.5

7) 平岩陸 ·谷川恭雄 ·森博嗣・朴相倰・杉浦立 : 引張応力を受ける繊維補強 コンクリートの変形挙動に関する解析的研究, 日本建築学会構造系論文集, No.578, pp.7-11, 2004.4

8) 鎌田敏郎・荒川健・栗原哲彦・六郷恵哲：コンクリートと鋼瀻維の付着特 性に関する基礎的研究, セメント・コンクリート論文集, No.52, pp.754-759, 1998.12

9) 清田雅量 · 三橋博三・閑田徹志・川又篤：䋐維補強セメント系複合材料に おける単緎維の引抜抵抗性能に関する実験的研究, セメント・コンクリート 論文集, No.56, pp.625-632, 2002.12

10)平岩陸・田中清人・谷川恭雄・森博嗣 : モルタル中の各種瀻維の引抜け特 性に関する基碟的研究, 日本建築学会大会学術講演梗概集(東海), A-1, pp.769-770, 2003.9

11)椿龍哉・田中健二郎：鋼織維の引き抜け特性に及ほすす付着長の影響, コン クリート工学論文集, Vol.12, No.2, pp.83-92, 2001.5 